Vol. 27, No. 2, December 2020

P-ISSN: 0854-8919, E-ISSN: 2503-1023

Nationally Accredited Journal, Decree of MoHE No. 148/M/KPT/2020.

\title{
A New Industry and Tax Base on Taxing Esports in Indonesia
}

\author{
Ming-Hsi Sung1, Wahyudi Umar ${ }^{2}$ \\ 1, 2 Department of Financial and Economic Law, Asia University, Taiwan \\ E-mail: ${ }^{1}$ minghsi_sung@asia.edu.tw \\ 2wydumar@gmail.com
}

\begin{tabular}{l} 
ARTICLE INFO \\
\hline Keywords: \\
esports; live game \\
streamer; platform; tax \\
base \\
How to cite: \\
Sung, M.-H., E Umar, W. \\
(2020). A New Industry \\
and Tax Base on Taxing \\
Esports in Indonesia. \\
Jurnal Media Hukum, \\
27(2), 147-165. \\
Article History: \\
Received: 05-12-2020 \\
Reviewed: 07-12-2020 \\
Revised: 31-12-2020 \\
Accepted: 31-12-2020 \\
\end{tabular}

\begin{abstract}
Unlike traditional sports that relies on traditional television broadcasting, esports usually adopts live streaming on internet platforms, such as YouTube, as its medium. Through a delicate design of profit sharing, live esports streaming and media have greatly changed the video game industry from sheer family entertainment machine makers into a new frontier of money making sport, and therefore the game players into a profession that may make billion dollars annually. This paper intends to introduce the current situation of esports in Indonesia, asserting the potential to collect tax from live game streamers (Content Creators) and YouTube (Platform), and players from this newly developed sports industry to broaden the tax base in Indonesia. This research is a normative legal research. Data collected from books, journals, relevant laws and regulations. The results show that the government should either revise the current tax law and legal design that are obvious out-ofdated and dysfunctional or follow developed countries to have law specifically designed for taxing esports industry and e-economy.
\end{abstract}

DOI: 10.18196/jmh.20200148

Copyright (C) 2020 JURNAL MEDIA HUKUM. All rights reserved.

\section{Introduction}

Esports (also called as electronic sports, or e-sports), or better known as online game sports, have recently been booming and becoming a billion-dollar industry in 2019. ${ }^{1}$ Esports even have become one of the officially included campaigns in the Olympics Games, ${ }^{2}$ following the Asian Games 2018 in Indonesia and the Sea Games 2019 in the Philippine, and it has also become a popular profession option. According to recent

1 CNBC, Here's why esports can become a billion-dollar industry in 2019, available at https://www.cnbc.com/2019/01/20/heres-why-esports-can-become-a-billion-dollar-industry-in2019.html (last visited February 2, 2020)

2 Baker, L. B., \& Carroll, R. Esports get a cool reception at Winter Games, available at https://www.reuters.com/article/us-olympics-2018-esports-idUSKBN1FR13Y (last visited May 16, 2020) 3 The Asian Games is a continental multi-sport event held every four years among athletes from all over Asia.

4 The Sea Games or Southeast Asian Games is a biennial multi-sport event involving participants form current 11 countries of Southeast Asia. 
statistics, the National Basketball Association prize pool is USD 13 million, for the Golf Masters is \$11 million, and for the Confederations Cup is USD 20 million. ${ }^{5}$ With a combined prize pool of USD 24.7 million, eSports meets each of the above mentioned. ${ }^{6}$ Nevertheless, what makes esports different is that traditional television broadcasting is not the primary medium distribution of esports. ${ }^{7}$

Fans watch esports games via live streaming gaming channels, such as YouTube, and Twitch, a dedicated web-based platform. In the first quarter of 2018, esports fans spent 17.9 million hours watching their gaming heroes on those platforms. ${ }^{8}$ Gaming has recently become a spectator form of entertainment. ${ }^{9}$ Live streaming has changed the game industry and transformed gaming into a profession that can earn a billion dollars in a year. For example, Tyler Blevins, a.k.a. Ninja ${ }^{10}$, has regularly earned USD 500.000 to $\$ 1$ million a month by playing video games. ${ }^{11}$ Tobias Justin, better known as "Jess No Limit", is an Indonesian popular YouTube streamer for the MOBA (Multiplayer online battle arena) style game, "Mobile Legends"12, which has over 156 million video views. He is estimated to earn USD 39.200 to $\$ 626.700$ in a month. ${ }^{13}$ Since game streamers have great influence when it comes to marketing esports to engage the audience through influencer marketing, celebrities' endorsement constitutes a crucial campaign tool. Therefore, the streamers and celebrities have heavily relied on each other to make a profit from esports.

Currently, Indonesia has 43.7 million players spending USD 880 million on eSports. ${ }^{14}$ This fact puts Indonesia the 16th in the world in terms of revenue from the world's largest game. ${ }^{15}$ Many tax implications have emerged as a result of the growth of the

5 World Economic Forum, The explosive growth of esports, available at https://www.weforum.org/agenda/2018/07/the-explosive-growth-of-esports/ (last visited February 6, 2020)

6 Nordmark, S \& Heath, J. The top 10 highest prize pools in eSports, available at https://dotesports.com/general/news/biggest-prize-pools-esports-14605 (last visited May 16, 2020)

7 Newzoo, The Global Esports Audience Will Be just Shy of 500 Million This Year, available at https://newzoo.com/insights/articles/newzoo-esports-sponsorship-alone-will-generate-revenues-ofmore-than-600-million-this-year/ (last visited February 4, 2020)

8 World Economic Forum, The explosive growth of esports, available at https://www.weforum.org/agenda/2018/07/the-explosive-growth-of-esports/ (last visited February 6, 2020)

9 Deng, J., Cuardrado, F., Tyson, G., \& Uhlig, S., 2015, Behind the Game: Exploring the Twitch Streaming Platform, 2015 International Workshop on Network and Systems Support for Games (NetGames), p. 1

10 Ninja is best known as a video game streamer and has over 14 million subscribers on Twitch and has over 17 million subscribers on YouTube.

11 Celebrity Net Worth, how much is Tyler "Ninja" Blevins Net Worth? available at https://www.celebritynetworth.com/richest-celebrities/rock-stars/tyler-ninja-blevins-net-worth/ (last visited May 9, 2020)

12 MOBA style games are definitely becoming a trend, however within this sub-genre there has still not been a decent game for smartphones and certainly not one that could ever come close to rivalling DOTA 2 or League of Legend. That being said, Mobile Legends has come up with a shameless but equally fun League of Legends clone with multi-player online gaming; and it should be said that it is up par with its PC counterparts.

13 Social Blade, Jess No Limit's YouTube Stats Summary, available at https://socialblade.com/youtube/channel/UCvh1at6xpV1ytYOAzxmqUsA (last visited May 9, 2020)

14 Bountie Gaming, There's A Huge Untapped Market For The Esports Industry In Asia \& You'll Lose Out If You Ignore It, available at https://medium.com/swlh/theres-a-huge-untapped-market-for-the-esportsindustry-in-asia-you-11-lose-out-if-you-ignore-it-cb261cc8cea (last visited May 19, 2020)

15 Azhar, R. eSports are at the Brink of Recognition as Athletes and Olympians, available at https://nowjakarta.co.id/life/techno/esports-are-at-the-brink-of-recognition-as-athletes-and-olympians (last visited May 19, 2020) 
digital industry of online video game streaming. Nevertheless, well-designed tax rules on esports remain unseen in Indonesia. Due to the fact that the income of game streamers and players is huge in Indonesia, collecting tax from them is an issue not only of tax equality but also financial urgency in Indonesia, which has faced serious state budget deficits recently. Therefore, this paper intends to introduce the current situation of esports in Indonesia, asserting that the potential to collect tax from live game streamers (Content Creators), platforms, and players from this newly developed esports industry can broaden the tax base and relieve fiscal problems in Indonesia.

\section{Method}

The type of this research is normative or doctrinal legal research that uses the law as a foundation of the norm. The norm system in question is related to principle, norm, legislation concerning the case quo. ${ }^{16}$ The first stage of normative research comprises research to achieve law's objective by conducting research on legal issues. The second stage of normative legal research aims at obtaining secondary data. ${ }^{17}$ It also concerns with a critical review of legislation. ${ }^{18}$ This research would use the statutory approach, which means using the legislation to conduct the research. ${ }^{19}$ The data were collected from books, journals, relevant laws, and regulations.

\section{Analysis and Results}

\subsection{Esports in Indonesia}

In Indonesia, eSport has existed since the 1990s. The Game League is a pioneer of eSports in Indonesia. ${ }^{20}$ According to Eddy Lim, the founder of Game League, like a social networking platform such as Facebook or Twitter, the League was formed because it has a purpose to gather gamers in Indonesia. ${ }^{21}$ In 2002, the Game League became the first gateway for the entry of the World Cyber Games (WCG) ${ }^{22}$ in Indonesia. ${ }^{23}$ Since then, because of the existence of esports, the ability of the athletes, and all the benefits of its ecosystem can be a source of the soft power ${ }^{24}$ of the country, ${ }^{25}$

\footnotetext{
16 Mukti, F.ND., \& Yulianto. (2010). Dualisme Penelitian Hukum (Dualism of Legal Research), Yogyakarta; Pensil Komunika, p. 34

17 Rusli, H. (2006). Metode Penelitian Normatif (Normative Research Methods), Jakarta; Gramedia Pustaka Utama, p. 50

18 Dyah, O. S., \& A'an, E. (2015), Penelitian Hukum (Legal Research), Jakarta; Sinar Grafika, p. 10

19 Ibrahin, J. (2005). Teori dan Metodologi Penelitian Hukum Normatif (Theory and Methodology of Nomative Legal Research), Second Edition, Malang; Bayu Media, p. 302

${ }^{20}$ Fachri, A. Seberapa Besar Potensi E-Sports di Indonesia (How Big is the Potential of E-Sports in Indonesia), available at https://www.kompasiana.com/anandafachri/5e676f0e097f362c062a2f34/seberapa-besarpotensi-e-sport-di-indonesia (last visited August 18, 2020)

${ }^{21}$ Aditia, R. N. Sejarah eSports Indonesia: Dari Warnet Menuju Panggung Dunia (History of Indonesian eSports: From Internet Cafes to the World Stage), available at https://kumparan.com/kumparansport/sejarahesports-indonesia-dari-warnet-menuju-panggung-dunia-1533295225512257378/full (last visited August $18,2020)$

${ }^{22}$ World Cyber Game (WCG) is a festival of global esports that began its first event in 2000. Since 2000, WCG has been recognized as the world's largest esports competitions.

23 Kurniawan, F. (2019). E-sport dalam Fenomena Olahraga Kekinian (E-sports in the Current Sports Phenomenon), JORPRES (Jurnal Olahraga Prestasi), p. 64

24 Soft power refers to the ability to shape the preferences of other parties or countries by attractive rather than coercion
} 
esports has been considered potential by the government. Many competitions with prizes of billion rupiahs have been held more frequently. ${ }^{26}$ To show her support and for fear of a violation of local culture and law, the government therefore issued Ministerial Regulation No. 11 of 2016 on the General Classification of Electronic Interactive Games (a.k.a. Indonesian Game Rating System, IGRS ), to regulate game distribution in the country and help parents ascertain which games are fitting for their children. ${ }^{27}$

After the 2018 Asian Games, which were held in Jakarta and Palembang, the government has paid great attention to esports. Before the 2019 SEA Games, the government intended to issue one more Ministerial Regulation because esports would also compete there. ${ }^{28}$ However, after going through some considerations and remembering that the government will revise the National Sport System Law, the government postponed the regulation and planned to make it into law. ${ }^{29}$ Recently, the Ministry of Youth and Sports (Kemenpora) will hold the 2020 Axis Esports Menpora Cup. According to Zainudin Amali, Miniter of Youth and Sports, the 2020 Menpora Cup is an implementation of government support for esports progress in Indonesia.

The progress of eSports in Indonesia is also marked by the formation of an organization called IeSPA (Indonesia eSports Association), a member of the IeSF (International eSport Federation). ${ }^{30}$ The government has strongly supported the development of esport in Indonesia through holding various video games or esports tournaments, such as the President's Cup in February 2020 and GELORA 2020 (Game Lokal Kreasi Indonesia/local Game Creation Indonesia). ${ }^{31}$ According to Giring Ganesha, President of the Indonesia Esports Premier League (IESPL), Indonesia is ranked the 12th in the world gaming market, with a total 62.1 million active gamers, and the market has generated revenue of 1.04 billion rupiahs in 2019. He concludes that three trends make esports increasingly popular among the public: the shift from PC to mobile, which makes esports more accessible through more practical and simpler devices; the shift from single-player to multiplayer, which demonstrates players' preference to play multiplayer mode games because they can build a spirit of

25 Rachman, B., Junita, et al, Esport Sebagai Sumber Soft Power Indonesia: Sosialisasi Kepada Anak Muda (Esports as a Source of Indonesian Soft Power: Socialization to Young People), CARADDE: Jurnal Pengabdian Kepada Masyarakat, Volume 3, Number 1, 2020, p. 44.

${ }^{26}$ Amalia, E. I., Daftar Turnamen Esports Berhadiah Terbesar di Indonesia 2019 (List of the Biggest Prize eSports Tournaments in Indonesia), available at https://hybrid.co.id/post/daftar-turnamen-esports-berhadiahterbesar-di-indonesia-2019 (last visited August 18, 2020)

27 See https://www.gameprime.org/2017/11/indonesia-game-rating-system-igrs/ (last visited August $18,2020)$

28 Ayudiana, Shofi, Peraturan Mentri Soal Esport Rampung Sebelum SEA Games 2019 (Ministerial Regulation

Concerning Esports Completed Before the 2019 SEA Games), available at https://www.antaranews.com/berita/1091884/peraturan-menteri-soal-esport-rampung-sebelum-seagames-2019 (last visited August 20, 2020)

${ }_{29}$ Rifki, Billy, Kemenpora "Godok" Undang-Undang Esports, Manfaatnya apa? (The Minister of Youth and Sports "Push" the Esports Law, What are the benefits?), available at https://esports.id/other/news/2020/02/0de5d1a081a3095d62b416e44e055e7a/kemenpora-godokundang-undang-esports-manfaatnya-apa (last visited August 20, 2020)

30 Anonymous, Sejarah Perkembangan IeSPA (History of IeSPA), available at http://www.iespa.or.id/sejarah-perkembangan/ (last visited May 19, 2020)

31 Iskandar, Merdi, Pemerintah Indonesia Dorong Pengembangan eSports Nasional (Indonesian Government Encourages the Development of National eSports), available https:// wartakota.tribunnews.com/2020/07/01/pemerintah-indonesia-dorong-pengembangan-esportsnasional (last visited July 17, 2020) 
togetherness; and the shift from playing to watching, which is evidenced by the phenomenon that the game enthusiasts watch some other players that have strategies in completing games through various digital platforms. ${ }^{32}$

The large and growing number of spectators makes esports an attractive business. According to the Newzoo report, in 2018, the number of esports viewers has reached 380 million. The number is expected to increase to 557 million in $2021 .{ }^{33}$ With the edge of employing live streaming as the medium for broadcasting, the esports industry has not been affected by the Covid-19 Pandemic. According to Syaifullah, the Director of Creative Industries, Film, Television, and Animation of the Ministry of Tourism and Creative Economy, in contrast to the other tourism and creative economy industries affected by the Covid-19 Pandemic, the growth of eSports in Indonesia has increased by 10 to 20 percent amid the Pandemic due to the surge of the use of digital platforms. ${ }^{34}$ The reason for the increase is that the format of an esports tournament during the Pandemic can be entirely held online, and viewers can also watch the competition through live streaming platforms without any social contact. ${ }^{35}$ IDC $^{36}$ and Esports Charts ${ }^{37}$ reports indicate that there are 15 esports tournaments held during the Pandemic. In 8 tournaments, the total video watching duration has increased ${ }^{38}$ because the esports tournament organizers decided to change the tournament format to an online arrangement. ${ }^{39}$

\subsection{Live Game Streamer in Indonesia}

Recently a new kind of social media, live streaming service, has emerged. One thereby can create a stream or watch someone's broadcasting over the internet. Unlike the other social media, the content is broadcasted and viewed synchronously on a live

\footnotetext{
32 Anggraeni, Lufthi, IESPL: Indonesia Peringkat 12 Pasar Gaming Dunia (IESPL: Indonesia Ranked 12 th in the World Gaming Market), available at https://www.medcom.id/teknologi/game/ybDl83Pb-iespl-indonesiaperingkat-12-pasar-gaming-dunia (last visited August 14, 2020)

33 Amalia, E. I., Kenapa Investor Percaya Esports Bakal Jadi Industri Bernilai US\$1 Milliar? (Why do Investors believe that esports will be a US\$1 Billion Industry?), available at https://hybrid.co.id/post/nilai-industriesports (last visited August 18, 2020)

34 Malena, Industri Gaming Tumbuh 20 Persen, Ini 3 Alasan eSports Kian Populer (Gaming Industry Grows 20 Percent, These are 3 Reason esports is Gaining More Popular), available at http:/ / www.kalderanews.com/2020/07/industri-gaming-tumbuh-20-persen-ini-3-alasan-esports-kianpopuler/ (last visited August 18, 2020)

35 Setyo Wardani, Agustin, Menakar Format Turnamen Esports di Masa Pandemi (Measuring the Format of Esports Tournaments during Pandemic), available at https://www.liputan6.com/tekno/read/4311170/menakar-format-turnamen-esports-di-masa-pandemi (last visited August 20, 2020)

36 International Data Corporation (IDC) is the premier global provider of market intelligence, advisory services, and events for the information technology, telecommunications, and consumer technology markets.

37 Esports Charts, a multi-sense big data-mining and analytical agency for esports, traditional sports, and entertainment, and one of the largest public sources of streaming analytics in the world.

38 Amalia, E. I., IDC:Viewership Turnamen Esports Naik 2 Kali Lipat Selama Pandami Corona (IDC: Viewership of Esports Tournaments Doubled During the Corona Pandemic), available at https://hybrid.co.id/post/idcviewership-turnamen-esports-naik-2-kali-lipat-selama-pandemi-corona (last visited August 20, 2020)

39 Amalia, E. I., Bagaimana Pengaruh Corona Pada Audiens Esports? (How Does Corona Affect the Esports Audience?), available at https://hybrid.co.id/post/bagaimana-pengaruh-corona-pada-audiens-esports (last visited August 20, 2020)
} 
streaming platform. ${ }^{40}$ Twitch is one of the most widely used live game streaming platforms. ${ }^{41}$ Amazon saw Twitch's great potential, and Twitch has become an Amazon property since August 2014. From 1.5 million broadcasters and 100 million monthly viewers in 2015, Twitch's traffic continued to rise to 2.2 million broadcasters and 15 million daily viewers in 2018. In early 2020, the average concurrent viewers were up to 1.4 million. The platform is integrated with Amazon Prime and enables streamers to make money by providing in-stream links that encourage viewers to purchase the game the streamers play. 42

Live game streaming is not a new thing in Indonesia. Game players have started doing live streaming on Twitch since 2011, although it was not very popular in Indonesia. ${ }^{43}$ The game streaming usually was similar to a conventional TV program with players commentating while playing a game, and the video content may be pre-recorded and edited. ${ }^{44}$ But the situation has changed after the fact that YouTube Gaming Channel was established in 2015 and has received a positive response in Indonesia. ${ }^{45}$ Currently, there are more than hundreds of game streamers on YouTube. Among them are some who stand out and make them the most popular YouTubers, and therefore profit makers. Nevertheless, the internet's revenues have not been fully comprehended by the existing tax law in Indonesia. Tax evasion becomes a critical issue for the government to resolve. 46

In 2019, there are 13 YouTuber game streamers/channels ${ }^{47}$ earning money up to billion-rupiah from YouTube per month. ${ }^{4}$ Nevertheless, YouTubers' income in

40 Zhao, Q., Chen, C.-D., Chen, H.-W., \& Wang, J.-L., Determinants of Live Streamers' Continuance Broadcasting Intention on Twitch: A Self-Determination Theory Perspective, Telematics and Informatics, 2018, p. 406.

${ }^{41}$ Gandolfi, E. To Watch or to Play, It Is in the Game: The Game Culture on Twitch.tv Among Performers, Play and Audiences, Journal of Gaming \& Virtual Worlds, 2016, p. 64

42 Iqbal, Mansoor, Twitch Revenue and Usage Statistics (2020), available at https://www.businessofapps.com/data/twitch-statistics/ (last visited July 17, 2020)

43 Ellavie Ichlasa A., Populer Secara Global, Twitch Tak Berkutik di Indonesia (Globally Famous, Twitch Does Not Do Anything in Indonesia), available at https://hybrid.co.id/post/populer-secara-global-twitch-takberkutik-di-indonesia (last visited June 4, 2020)

${ }^{44}$ King, D. L., \& Delfabbro, P.H., (2019), Introdcution to Gaming and IGD, Internet Gaming Disorder, p. 10

45 Kusuma, A., 4 Nama Besar Platform Streaming Terkait Video Games Beserta Pros Dan Cons (4 Name of the Platform Related Streaming Video Games And Its Pros And Cons), available at https://gamebrott.com/4nama-besar-platform-streaming-terkait-video-games-beserta-pros-dan-cons (last visited June 4, 2020)

46 Van Dijck, J., Governing Digital Societies: Private Platforms, Public Values, Computer Law E Security Review, November 2019, p. 1

47 Income per month 13 YouTuber gaming in Indonesia reported from iconographic Katadata.co.id, are:

1. MiawAug (subscriber: 6,3M) 270 million to 4.3 billion rupiah

2. Jess No Limit (subscriber: $6 \mathrm{M}$ ) 137 million to 2.2 billion rupiah

3. DylandPros (subscriber: 5.3M) 106 million to 1.7 billion rupiah

4. Frost Diamond (subscriber: 4.6M) 204 million to 3.3 billion rupiah

5. Kemas pake z (subscriber: $4.4 \mathrm{M}$ ) 125 million to 2 billion rupiah

6. Erpan1140 (subscriber: $4.2 \mathrm{M}$ ) 134 million to 2.2 billion rupiah

7. Rendy Rangers (subscriber: 3.2M) 146 million to 2.3 billion rupiah

8. Afif Yulistian (subscriber: 3M) 38 million to 600 million rupiah

9. Wawan MKS (subscriber: 2.8M) 98 million to 1.6 billion rupiah

10. Bang Alex (subscriber: $2.6 \mathrm{M}$ ) 98 million to 1.6 billion rupiah

11. MILYHYA (subscriber: $2.4 \mathrm{M}$ ) 67 million to 1.1 billion rupiah

12. Hi Patrick (subscriber: $2.3 \mathrm{M}$ ) 32 million to 517 million rupiah

13. Kimi Hime (subscriber:2.2M) 33.5 million to 534 million rupiah

48 Budiansyah,A, Ini Penghasilan 13 YouTuber Gaming Indonesia, Ratusan Juta Coy! (This is the income of 13 th YounTuber Gaming Indonesia, Hundreds Millions Coy!), available at 
Indonesia has not been subject to Indonesian income tax. This fact is evidenced by the absence of proof of deduction or proof of tax payments attached to the payment invoice received by the YouTubers when withdrawing money from the bank or West Union. ${ }^{49}$ It indicates that tax evasion can be a serious issue in this field, and therefore live game streaming can become an object of taxation. The income sometimes is intentionally transformed into a different form but currencies. For example, Facebook began to enter this business and has a market value of US $\$ 160$ billion. ${ }^{50}$

The salary for a live game streamer who has become an official Facebook partner is around 15 million to 100 million rupiahs. ${ }^{51}$ Unlike YouTube, Facebook has its currency for gaming, "stars, " and the user can buy stars with real money for gifts. ${ }^{52}$ In a live stream, viewers can engage with the Streamer by sending presents, donations, and feedbacks that are often scrolled through the screen in real-time. ${ }^{53}$ It is worth noting that donations and gifts are real money (Figure 1, Figure 2). But gifts (stars) given to the Streamer possess some advantage compared to a traditional tax haven. The gifts are saved in the online wallet of the Streamer in the form of stars, and then the Streamer may convert the stars to real money (Figure 3). ${ }^{54}$ Unlike a traditional tax haven, the online wallet does not operate in any jurisdiction and is not subject to any taxation. ${ }^{55}$ It makes tax evasion easier than a traditional tax haven.

\footnotetext{
https://nextren.grid.id/read/011800565/ini-penghasilan-13-youtuber-gaming-indonesia-ratusan-juta-coy (last visited June 5, 2020)

49 Vikansari., Suci, NP., Prasa., I Wayan, Pengawasan Pengenaan Pajak Penghasilan Terhadap YouTubers Sebagai Pelaku Influencer di Platform Media Sosial YouTube (Supervision of Income Tax Imposition of YouTubers as Influencer on the Youtube Social Media Platform), Kertha Negara: Journal Ilmu HukumI, Volume 7, No. 2, February 2019, p. 13

50 CNBC Indonesia, Halo Gamers, Ini Cara Dapat Uang dari Facebook Gaming! (Hallo Gamers, Here's How to Make Money from Facebook Gaming!), available at https://www.cnbcindonesia.com/tech/2020051117003637-157674/halo-gamers-ini-cara-dapat-uang-dari-facebook-gaming (last visited July 8, 2020)

51 Aditya, David, Dapat Gaji dari Facebook Lewat Live Streaming Game Favoritmu (Get Salaries from Facebook through Live Streaming of Your Favorite Games), available at http:// www.purwakartapost.co.id/16/07/2019/hiburan/dapat-gaji-dari-facebook-lewat-live-streaminggame-favoritmu/19333/ (last visited June 7,2020 )

52 Clinten, Bill, Begini Cara Gamer Dapat Uang dari Facebook Gaming (Here's How Gamers Can Earn Money form Facebook Gaming), available at https://tekno.kompas.com/read/2020/05/08/19150007/begini-caragamer-dapat-uang-dari-facebook-gaming?page=all (last visited June 28, 2020)

53 Zhou, J., Zhou, J., Ding, Y., \& Wang, H., The Magic of Danmaku: A Sosial Interaction Perspective of Gift Sending on Live Streaming Platforms, Electronic Commerce Research and Applications, 2019, p. 2

54 Rizkia, C., Tiga Cara Gamer Menghasilkan Uang Dari Faceboook Gaming (Three Ways Gamers Make Money from Facebook Gaming), available at https://technologue.id/tiga-cara-menghasilkan-uang-dari-facebookgaming/amp/ (last visited July 8, 2020)

55 Zucman, G., 2015, The Hidden Wealth of Nations: The Scourge of Tax Havens, University of Chicago Press, Chicago, p. 2.
} 




Figure 1. Live Streamer got donation about $\$ 1.000$ on YouTube



Figure 2. Live Streamer got donation about $\$ 100.000$ on Twitch 


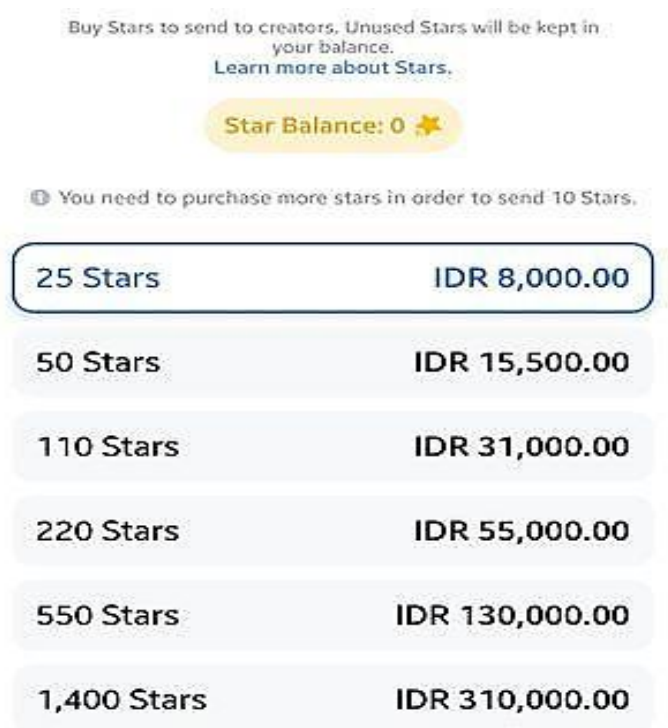

Figure 3. Facebook Gaming' Currency

\subsection{To Tax or Not to Tax, That Is A Question in Indonesia}

Indonesia is a rule of law state. ${ }^{56}$ All actions taken by the government must be based on existing legislation. ${ }^{57}$ Without any clear regulation that may cover the issue of live game streaming taxation, the government of Indonesia cannot do anything legally. However, if there is a law regulating the tax issues regarding esports, Indonesia may gain around 12.4 billion rupiahs from one live game streamer a year. ${ }^{58}$ Taxing esports can help the government fulfill yearly tax revenue targets easily and relieve Indonesia's fiscal shortfall burden. Nevertheless, current legislation in Indonesia is not enough to address the esports taxation issue.

\subsection{The Challenges of Live Game Streamer and Platform/YouTube Taxation to Indonesian Tax Law}

Indonesia does not have any specific regulation on the taxation of live game streamers (content creators) and YouTube (platforms). Currently the Law No. 36 of 2008 on Income Tax governs income tax matters. Article 4 (1) stipulates that "taxable object is income, which is defined as any increase in economics capacity received by or accrued by a Taxpayer from Indonesia as well as from offshore, which may be utilized for consumption or increasing the taxpayer's wealth, in whatever name and form,...". ${ }^{5}$ But the government has faced tasks regarding how to calculate income and to collect tax from the income. Meanwhile, although Article 3 provides that non-resident taxpayers can be qualified as tax subjects, it also requires the non-resident taxpayers

\footnotetext{
56 Per 1945 Constitution of Republic of Indonesia Article 1 (3) The State of Indonesia is a state based on the rule of law

57 Satriya,B., 2016, Membangun Negara Hukum di Era Pemerintahan Presiden Joko Widodo (Building the State of Law in the Era of President Joko Widodo), Jurnal Panorama Hukum, Volume 1, No. 2, p. 45

58 Calculation of MiawAug's income tax based on calculation system mentioned in Law No. 36 of 2008 on Income Tax

59 Article 4 Law No. 36 of 2008 on Income Tax, see https://www.expat.or.id/info/2008-IncomeTaxSDSNAmendment.pdf
} 
either "conducting business or carrying out activities through a permanent establishment," or "may receive or accrue income from Indonesia other than from conducting business or carrying out activities through a permanent establishment in Indonesia." Is YouTube or other platforms considered a permanent establishment in Indonesia? The current law have great definitional, interpretational, and technical difficulties when the government applies the law to the esports industry. Therefore, the current tax law faces insurmountable difficulties under current legal design.

\subsubsection{Taxing Live Game Streamer}

It is unarguable that live game streamers' money received from platforms, even though sometimes it has been transformed into other formats such as "stars," is income in terms of the Tax Law. Nevertheless, the problem for the government to tax the esports streamers lies in the way to collect it. Indonesia adopts a self-assessment system for tax collection in which the amount of tax owed by the taxpayers is self-determined. ${ }^{60}$ The government is only tasked to provide information and supervision. Thus, the success or failure of the implementation of tax collection is heavily dependent on taxpayers' honesty. This honesty issue may become the obstacle to impose a tax on the case a quo. ${ }^{61}$

Moreover, calculating income is also technically problematic in Indonesian tax law. According to Article 1 of the Regulation of Directorate General of Taxation No. PER$17 / \mathrm{PJ} / 2015$ regarding the norm of Net Income Calculation, the task of income calculation basically relies on taxpayer's book/record-keeping. ${ }^{62}$. Streamers' income calculation is a complex process that is decided by various factors, such as cost per miles (CPM), gifts, and donations, through specific rules provided by each platform. Because computerized inspection systems surely can manage fiscal risk better than manual book-keeping, 63 the Directorate General of Tax has tried to resolve the calculation problem by adopting an innovative system called SONETA (Social Network Analytics System) ${ }^{64}$ to monitor streaming activities. But the monitoring

\footnotetext{
${ }^{60}$ Law No. 16 of 2000 Article 12 (1) Every Taxpayer shall be obliged to pay tax payable pursuant to the provisions of the tax laws without waiting for the issuance of notice of tax assessment. (2) The amount of tax payable as stated in a Tax Return filed by a Taxpayer is the amount of tax payable pursuant to the provisions of tax laws. See also Imron Rizki A., July 2018, Self Aseesment Sistem Sebagai Dasar Pemungutan Pajak di Indonesia (Self-Assessment as a Basis for Tax Collection in Indonesia), Kendari: Jurnal Al-'Adl, Volume 11, Issue 2, p. 84-85; Nuramalia Hasanah, Susi Indriani, 2013, Efektifitas Pelaksanaan Self-Assessment System dan Modernisasi Administrasi Pajak Terhadap Kualitas Pelayanan Pajak (Studi Kasus Pada KPP Kebon Jeruk 1) (Effectiveness of Self-Assessment system Implementation and Modernization of Tax Administration on Tax Service Quality (Case Study on Kebun Jeruk 1), Semarang: Jurnal Ilmiah Wahana Akutansi, Volume 8, No. 1, p. 17-18 61 Farouq, M. March (2018), Hukum Pajak di Indonesia, Suatu Pengantar Ilmu Hukum Terapan di Bidang Perpajakan (Tax Law in Indonesia, An Introduction to Applied Legal Studies in the Field of Taxation), Jakarta: Prenada Media Group, p. 163

62 Directorate General Tax Regulation No.PER-17/JP/2015 on the norm of Net Income Calculation, article 1 (1) Individual taxpayer who carry out business activities in gross income of 4.8 billion rupiah or more a year are required to keep books (Pembukuan). (2) Individual taxpayers who carry out business or independent activities in gross income is within one year of less than 4.8 billion must hold records (Pencatatan), unless the relevant taxpayer chooses keep bookkeeping (Pembukuan).

63 Faúndez-Ugalde, A., Mellado-Silva, R., \& Aldunate-Lizana, E., Use of artificial intelligence by tax administrations: An analysis regarding taxpayers' rights in Latin American countries. Computer Law $\mathcal{E}$ Security Review, 2020, p. 1.

${ }^{64}$ SONETA is a system used to monitor every movement of influencers' activities such as Youtubers and celebrities who promote products, exhibits assets on social media or have income on certain social media platforms. See Indopajak.id, SONETA si Pemantau Pajak (SONETA the Tax Monitor), available at https://indopajak.id/pemantau-pajak-selebgram-dan-youtubers/ (last visited June 7, 2020)
} 
process with SONETA has failed, tax officers remain monitor streamers' activities in person. ${ }^{65}$ Besides the obvious short-staff difficulty in monitoring, it is also possible that there will be live game streamers not identified and thus un-monitored. The risk of tax loss remains potential.

According to Darussalam, a prestigious Tax Consultant of DDTC Consulting, many digital platforms are required to work with tax authorities to open transaction data in many countries. Thus, income streams or transactions of esports can be mapped. ${ }^{66}$ Tax avoidance and evasion are the main issues posed by adopting the tax return method to calculate income. Skepticism to tax data is normal, and thus inspection and monitoring are necessary. In other words, tax reports only include information about income reported to the tax authorities, but not real economic income. ${ }^{67}$

Besides deliberate tax evasion/avoidance, ignorance also contributes to the tax loss in esports tax collection.68 Sometimes live streamers fail to fulfill their tax-paying obligation simply because of a lack of knowledge about the tax collection mechanism. ${ }^{69}$ Therefore, the government has problems in finding a right formulation to tax streamers, and streamers have difficulties in seeking to pay tax.

\subsubsection{Taxing Platform Providers/YouTube}

As abovementioned, esports platform providers could be interpreted as tax subjects, so long as they meet the requirements for a non-resident taxpayer and permanent establishment stipulated in Article 2 of Law No. 36 of 2008 in Indonesia. Nevertheless, this out-of-date legal design simply makes taxing the platform providers difficult, if not impossible in the digital era. Indonesia can only use the tax law to collect tax from companies that are physically presented or have a permanent establishment (Bentuk Usaha Tetap/BUT) in her territory, whereas, in the current era with high technological development, more and more companies only appear online digitally. ${ }^{70}$

The government has tried to find a way to tax foreign companies that do not have a permanent establishment in Indonesia. A new bill (RUU), which will replace Law No. 28 of 2007 on General Provisions of Tax, has been proposed to contain foreign entities

\footnotetext{
65 Vikansari., Suci, NP., Prasa., I Wayan, Pengawasan Pengenaan Pajak Penghasilan Terhadap YouTubers Sebagai Pelaku Influencer di Platform Media Sosial YouTube (Supervision of Income Tax Imposition of YouTubers as Influencer on the Youtube Social Media Platform), Kertha Negara: Journal Ilmu Hukum, Volume 7, No. 2, February 2019, p. 13

66 Muhammad, F., Bagaimana Cara Agar Youtuber Indonesia Mau Bayar Pajak? (How do you get Indonesian YouTubers to Pay Taxes?), available at https://www.cnbcindonesia.com/news/20190113154724-450418/bagaimana-cara-agar-youtuber-indonesia-mau-bayar-pajak (last visited August 5, 2020)

67 Alstadseaster, A., Johannesen, N., \& Zucman, G., Who Own the Wealth in Tax Havens? Macro Evidence and Implications for Global Inequality, Journal of Public Economics, January 2018, p. 90.

68 Situmorang, A.P., Ini Alasan YouTuber dan Selebgram Mangkir Bayar Pajak (This is the Reason Why YouTuber and Celebirty are Absent from Paying Taxes), available at https://www.merdeka.com/uang/inialasan-youtuber-dan-selebgram-mangkir-bayar-pajak.html (last visited August 5, 2020)

69 BPPM Mahkamah, Endorsers: Wajib pajak atau sekedar Subjek Pajak? (Endorsers: Taxpayers or jus Tax Subjects?), available at https://mahkamahnews.org/2019/09/03/endorsers-wajib-pajak-atau-sekadarsubjek-pajak/ (last visited August 5, 2020)

70 Julita S., Lidya, Saat Dirjen Kemenkeu Cerita Kenapa Susah Memajaki Google Cs (When Director General of Ministry of Finance Tells Why It's Difficult to Tax Google Cs), available at https:// www.cnbcindonesia.com/tech/20190717154401-37-85636/saat-dirjen-kemenkeu-cerita-kenapasusah-memajaki-google-cs (last visited August 5, 2020)
} 
doing business but without permanent establishment in Indonesia. ${ }^{71}$ Hence, the definition of a non-resident tax subject will not be based on the form of its permanent establishment, but on its business in Indonesia.

\begin{tabular}{llccc}
\hline \multirow{2}{*}{ No. Country } & & $\begin{array}{c}\text { Corporate } \\
\text { Income }\end{array}$ & Capitals Gain & Branch \\
\cline { 3 - 5 } & & Tax Rate $(\%)$ & Tax Rate $(\%)$ & Tax Rate $(\%)$ \\
\hline 1. & Argentina & 35 & 35 & 35 \\
2. & Australia & 20 & 30 & 30 \\
3. & Brazil & 15 & 15 & 15 \\
4. & Canada & 15 & 7.5 & 15 \\
5. & China & 25 & 25 & 25 \\
6. & France & $331 / 3$ & $0 / 15 / 331 / 3$ & $331 / 3$ \\
7. & Germany & 15 & 15 & 15 \\
8. & Indonesia & 25 & - & - \\
9. & India & 30 & 20 & 40 \\
10. & Italy & 27.5 & $1.37 / 27.5$ & 27.5 \\
11. & Japan & 25.5 & 25.5 & 25.5 \\
12. & Republic of Korea & 22 & 22 & 22 \\
13. & Mexico & 30 & 30 & 30 \\
14. & Russia & $5 / 20$ & $5 / 20$ & $5 / 20$ \\
15. & Saudi Arabia & 30 to 85 & 20 & - \\
16. & South Africa & 28 & 18.65 & 28 \\
17. & Turkey & 20 & 20 & 20 \\
18. & United Kingdom & 24 & 24 & 24 \\
19. & United States & 35 & 35 & 35 \\
20. & European Union & 24 & 24 & 24 \\
\hline
\end{tabular}

Table 1. Tax rate from other countries

Besides, in light of the rapid development of technology, the government also notices that tax object reformulation can be one of the ways to deal with the current taxation predicament.72 Internet-based or over-the-top (OTT) digital companies, such as Google, YouTube, and Facebook, are among the government's list of the trial to collect the tax. ${ }^{73}$ Google Indonesia (GI) has already paid 10\% value-added tax for its OTT service in Indonesia. This success hopefully, can set up a model for collecting tax from multinational online service providers. ${ }^{74}$ This trial is also in line with the current mandate to

\footnotetext{
${ }^{71}$ Rizkia, C., Bisakah Skema Pungut Pajak Netfilx Mencontek Singapura? (Can Indonesia Imitate Singapore on the Netflix Tax Collection Scheme?), available at https://technologue.id/bisakah-skema-pungut-pajak-netflixmencontek-singapura/amp/ (last visited August 25, 2020)

72 Nurhayat, W., Ekonomi Digital Jadi Tantangan Terberat Dirjen Pajak (Digital Economy Becomes the Most Challenging Director General of Taxes), available at https://kumparan.com/kumparanbisnis/ekonomidigital-jadi-tantangan-terberat-ditjen-pajak-27431110790545513/full (last visited August 5, 2020)

${ }^{73}$ Isna, R. S. R., Sri Mulyani Beberkan Tantangan Dirjen Pajak di Era Digital (Sri Mulyani Outlines the Challenges of the Director General of Taxes in the Digital Era), available at https://www.inews.id/finance/makro/sri-mulyani-beberkan-tantangan-ditjen-pajak-di-era-digital (last visited August 5, 2020)

74 Yadika, Bawono, Facebook, YouTube dan Twitter Diminta Tiru Google soal Bayar Pajak (Facebook, YouTube and Twitter asked to imitate Google about Paying Taxes), available at
} 
tax the digital economy adopted by the OECD and many developed countries (Table 1). ${ }^{75}$

\section{Conclusion}

As a new multi-billion business, Esports can be a new tax base to increase the fiscal budget and resolve the state budget deficit. Moreover, in light of taxation and policing tax avoidance/evasion, the government must collect tax from this new industry. Meanwhile, with the development of technology, Indonesia should either revise the current tax law or follow developed countries to have a law specifically designed to tax esports and e-economy.

\section{References}

Books:

Ali, A. (2017). Menguak Teori Hukum (Legal Theory) dan Teori Peradilan (Judicial Prudence) Termasuk Interpretasi Undang-Undang (Legisprudence) (Revealing Legal Theory and Judicial Theory, including Interpretation of Law). Jakarta: Kencana.

Deng, J., Cuardrado, F., Tyson, G., \& Uhlig, S.. (2015). Behind the Game: Exploring the Twitch Streaming Platform. 2015 International Workshop on Network and Systems Support for Games (NetGames).

Dyah, O. S., \& A'an, E. (2015), Penelitian Hukum (Legal Research), Jakarta; Sinar Grafika

Farouq, M. (2018). Hukum Pajak di Indonesia, Suatu Pengantar Ilmu Hukum Terapan di Bidang Perpajakan (Tax Law in Indonesia, An Introduction to Applied Legal Studies in the Field of Taxation). Jakarta: Prenada Media Group.

Ibrahin, J. (2005). Teori dan Metodologi Penelitian Hukum Normatif (Theory and Methodology of Nomative Legal Research), Second Edition, Malang; Bayu Media

King, D. L., \& Delfabbro, P.H. (2019). Introdcution to Gaming and IGD. Internet Gaming Disorder.

Mukti, F.ND., \& Yulianto. (2010). Dualisme Penelitian Hukum (Dualism of Legal Research). Yogyakarta; Pensil Komunika.

Rusli, H. (2006). Metode Penelitian Normatif (Normative Research Methods), Jakarta; Gramedia Pustaka Utama, p. 50

Zucman, G.. (2015). The Hidden Wealth of Nations: The Scourge of Tax Havens. University of Chicago Press, Chicago.

https://www.liputan6.com/bisnis/read/4052109/facebook-youtube-dan-twitter-diminta-tiru-googlesoal-bayar-pajak (last visited August 25, 2020)

75 Zainal Arifin, Nanang, BEPS Dalam Kerangka Kerja Sama G20 dan Implementasinya Kepad Indonesia (BEPS In the Framework of G20 Cooperation and Its Implementation to Indonesia), available at https://www.kemenkeu.go.id/sites/default/files/beps \%20dalam \%20kerangka \%20kerja\%20sama \%20g20 \%20dan\%20implementasinya \%20kepada \%20indonesia.pdf (last visited August 5, 2020) 


\section{Journal Articles;}

Alstadseaster, A., Johannesen, N., \& Zucman, G. (2018). Who Own the Wealth in Tax Havens? Macro Evidence and Implications for Global Inequality, Journal of Public Economics. 89-100. 90.

Dian Lesari, D., Ainul, et. al. (2019). Analisis Pelaksanaan Pengawasan Pengenaan Pajak Penghasilan Atas Penghasilan Youtubers Pada Direktorat Jendral Pajak Tahun 2018 (Analysis of the Implementation of the Supervision of Income Tax Imposition on Youtubers Income at the 2018 Directorate General of Tax).Jurnal Reformasi Administrasi.Volume 6. No. 2. 144-162. 145.

Faúndez-Ugalde, A., Mellado-Silva, R., \& Aldunate-Lizana, E. (2020). Use of artificial intelligence by tax administrations: An analysis regarding taxpayers' rights in Latin American countries. Computer Law \& Security Review. 1-14. 1.

Gandolfi, E.. (2016). To Watch or to Play, It Is in the Game: The Game Culture on Twitch.tv Among Performers, Play and Audiences. Journal of Gaming E Virtual Worlds. Volume 8. Number 1. 61-82. 64.

Hasanah, N., \& Indriani, S. (2013). Efektifitas Pelaksanaan Self-Assessment System dan Modernisasi Administrasi Pajak Terhadap Kualitas Pelayanan Pajak (Studi Kasus Pada KPP Kebon Jeruk 1) (Effectiveness of Self-Assessment system Implementation and Modernization of Tax Administration on Tax Service Quality (Case Study on Kebun Jeruk 1). Jurnal Ilmiah Wahana Akutansi. Volume 8. No. 1. 17-53. 17-18.

Karadag, N.C. (2019). Internet Ortaminda Verilen Reklam Hizmetlerinin Vergilendirilmesi (Taxation of Advertising Services Via the Internet), Makaleler. Number 236. 74-89.74.

Kurniawan, F. (2019). E-sport dalam Fenomena Olahraga Kekinian (E-sports in the Current Sports Phenomenon). JORPRES (Jurnal Olahraga Prestasi). 15 (2). 61-66. 64.

Luban, D.. (2015). Justice and Law. International Encyclopedia of the Social \& Behavioral Sciences. 932-936. 932.

Rachman, B., Junita, et al. (2020). Esport Sebagai Sumber Soft Power Indonesia: Sosialisasi Kepada Anak Muda (Esports as a Source of Indonesian Soft Power: Socialization to Young People). CARADDE: Jurnal Pengabdian Kepada Masyarakat.Volume 3. Number 1. 43-52. 44

Rizki A, I. (2018). Self Aseesment Sistem Sebagai Dasar Pemungutan Pajak di Indonesia (Self-Assessment as a Basis for Tax Collection in Indonesia). Jurnal Al-'Adl. Volume 11. Issue 2. 81-88. 84-85.

Satriya, B. (2016). Membangun Negara Hukum di Era Pemerintahan Presiden Joko Widodo (Building the State of Law in the Era of President Joko Widodo). Jurnal Panorama Hukum. Volume 1. No. 2. 43-54, 45.

Suparna, W., et. al. (2017). Analisa Upaya Peningkatan Penerimaan Perpajakan Dari Penggalian Potensi Pajak Atas Penghasilan YouTuber (Analysis of Tax Revenue Improvement Efforts Potential Exploration Taxes on YouTuber's Income). Journal Manajemen Keuangan Publik. Volume 1. No. 2. 125-130. 128. 
Van Dijck, J.. (2019). Governing Digital Societies: Private Platforms, Public Values. Computer Law \& Security Review. 36. 1-4. 1.

Vikansari., Suci, NP., Prasa., I Wayan. (2019). Pengawasan Pengenaan Pajak Penghasilan Terhadap YouTubers Sebagai Pelaku Influencer di Platform Media Sosial YouTube (Supervision of Income Tax Imposition of YouTubers as Influencer on the Youtube Social Media Platform). Kertha Negara: Journal Ilmu HukumI. Volume 7. No. 2. 1-15. 13

Zhao, Q., Chen, C.-D., Chen, H.-W., \& Wang, J.-L.. (2018). Determinants of Live Streamers' Continuance Broadcasting Intention on Twitch: A SelfDetermination Theory Perspective. Telematics and Informatics. 406-420. 406.

Zhou, J., Zhou, J., Ding, Y., \& Wang, H.. (2019). The Magic of Danmaku: A Sosial Interaction Perspective of Gift Sending on Live Streaming Platforms. Electronic Commerce Research and Applications. 1-9. 1.

\section{Legislation:}

1945 Constitution of Republic of Indonesia.

Law No. 36 of 2008 on Income Tax.

Law No. 6 of 1983 jo Law No. 16 of 2000 on General Provision and Tax Procedures.

Directorate General Tax Regulation No.PER-17/JP/2015 on the norm of Net Income Calculation.

\section{Internet:}

Aditia, R. N. Sejarah eSports Indonesia: Dari Warnet Menuju Panggung Dunia (History of Indonesian eSports: From Internet Cafes to the World Stage), available at https://kumparan.com/kumparansport/sejarah-esports-indonesia-dariwarnet-menuju-panggung-dunia-1533295225512257378/full (last visited August 18, 2020).

Aditya, D. Dapat Gaji dari Facebook Lewat Live Streaming Game Favoritmu (Get Salaries from Facebook through Live Streaming of Your Favorite Games), available at http://www.purwakartapost.co.id/16/07/2019/hiburan/dapat-gaji-darifacebook-lewat-live-streaming-game-favoritmu/19333/ (last visited June 7, 2020).

Alexy, R. Gustav Radbruch's Concept of Law, available at https://www.upjs.sk/public/media/16913/Gustav\%20Radbruch\%27s\%20Con cept \% 20of\%20Law.pdf (last visited July 12, 2020).

Amalia, E. I. Bagaimana Pengaruh Corona Pada Audiens Esports? (How Does Corona Affect the Esports Audience?), available at https://hybrid.co.id/post/bagaimanapengaruh-corona-pada-audiens-esports (last visited August 20, 2020).

Amalia, E. I. Daftar Turnamen Esports Berhadia Terbesar di Indonesia 2019 (List of the Biggest Prize esports Tournaments in Indonesia), available at https://hybrid.co.id/post/daftar-turnamen-esports-berhadiah-terbesar-diindonesia-2019 (last visited August 18, 2020). 
Amalia, E. I. IDC:Viewership Turnamen Esports Naik 2 Kali Lipat Selama Pandami Corona (IDC: Viewership of Esports Tournaments Doubled During the Corona Pandemic), available at https://hybrid.co.id/post/idc-viewership-turnamen-esports-naik2-kali-lipat-selama-pandemi-corona (last visited August 20, 2020).

Amalia, E. I. Kenapa Investor Percaya Esports Bakal Jadi Industri Bernilai US\$1 Milliar? (Why do Investors believe that esports will be a US\$1 Billion Industry?), available at https://hybrid.co.id/post/nilai-industri-esports (last visited August 18, 2020).

Amalia, E. I. Populer Secara Global, Twitch Tak Berkutik di Indonesia (Globally Famous, Twitch Does Not Do Anything in Indonesia), available at https://hybrid.co.id/post/populer-secara-global-twitch-tak-berkutik-diindonesia (last visited June 4, 2020).

Anggraeni, L. IESPL: Indonesia Peringkat 12 Pasar Gaming Dunia (IESPL: Indonesia Ranked $12^{\text {th }}$ in the World Gaming Market), available at https://www.medcom.id/teknologi/game/ybDl83Pb-iespl-indonesiaperingkat-12-pasar-gaming-dunia (last visited August 14, 2020).

Anonymous, Sejarah Perkembangan IeSPA (History of IeSPA), available at http://www.iespa.or.id/sejarah-perkembangan/ (last visited May 19, 2020)

Ayudiana, S, Peraturan Mentri Soal Esport Rampung Sebelum SEA Games 2019 (Ministerial Regulation Concerning Esports Completed Before the 2019 SEA Games), available at https://www.antaranews.com/berita/1091884/peraturan-menteri-soal-esportrampung-sebelum-sea-games-2019 (last visited August 20, 2020).

Azhar, R. eSports are at the Brink of Recoqnition as Athletes and Olympians, available at https://nowjakarta.co.id/life/techno/esports-are-at-the-brink-of-recognitionas-athletes-and-olympians (last visited May 19, 2020).

Baker, L. B., \& Carroll, R. Esports get a cool reception at Winter Games, available at https://www.reuters.com/article/us-olympics-2018-esports-idUSKBN1FR13Y (last visited May 16, 2020).

BPPM Mahkamah, Endorsers: Wajib pajak atau sekedar Subjek Pajak? (Endorsers: Taxpayers or jus Tax Subjects?), available at https://mahkamahnews.org/2019/09/03/endorsers-wajib-pajak-atau-sekadarsubjek-pajak/ (last visited August 5, 2020).

Budiansyah, A. Ini Penghasilan 13 YouTuber Gaming Indonesia, Ratusan Juta Coy! (This is the income of $13^{\text {th }}$ YouuTuber Gaming Indonesia, Hundreds Millions Coy!), available at $\quad$ https://nextren.grid.id/read/011800565/ini-penghasilan-13-youtubergaming-indonesia-ratusan-juta-coy (last visited June 5, 2020).

Celebrity Net Worth, how much is Tyler "Ninja" Blevins Net Worth? available at https://www.celebritynetworth.com/richest-celebrities/rock-stars/tyler-ninjablevins-net-worth/ (last visited May 9, 2020).

Clinten, Bill, Begini Cara Gamer Dapat Uang dari Facebook Gaming (Here's How Gamers Can Earn Money form Facebook Gaming), available at https://tekno.kompas.com/read/2020/05/08/19150007/begini-cara-gamerdapat-uang-dari-facebook-gaming?page=all (last visited June 28, 2020). 
CNBC Indonesia, Halo Gamers, Ini Cara Dapat Uang dari Facebook Gaming! (Hallo Gamers, Here's How to Make Money from Facebook Gaming!), available at https://www.cnbcindonesia.com/tech/20200511170036-37-157674/halogamers-ini-cara-dapat-uang-dari-facebook-gaming (last visited July 8, 2020).

CNBC, Here's why esports can become a billion-dollar industry in 2019, available at https://www.cnbc.com/2019/01/20/heres-why-esports-can-become-a-billiondollar-industry-in-2019.html (last visited February 2, 2020).

Fachri, A. Seberapa Besar Potensi E-Sports di Indonesia (How Big is the Potential of E-Sports in Indonesia), available at https://www.kompasiana.com/anandafachri/5e676f0e097f362c062a2f34/seber apa-besar-potensi-e-sport-di-indonesia (last visited August 18, 2020).

Gaming, B. There's A Huge Untapped Market For The Esports Industry In Asia E You'll Lose Out If You Ignore It, available at https://medium.com/swlh/theres-a-hugeuntapped-market-for-the-esports-industry-in-asia-you-ll-lose-out-if-you-ignoreit-cb261cc8cea (last visited May 19, 2020)

https://www.kemenkeu.go.id/sites/default/files/beps\%20dalam\%20kerangk a \%20kerja \%20sama \%20g20\%20dan \%20implementasinya \%20kepada\%20indone sia.pdf (last visited August 5, 2020).

Indopajak.id, SONETA si Pemantau Pajak (SONETA the Tax Monitor), available at https://indopajak.id/pemantau-pajak-selebgram-dan-youtubers/ (last visited June 7, 2020).

Iqbal, M. Twitch Revenue and Usage Statistics (2020), available at https://www.businessofapps.com/data/twitch-statistics/ (last visited July 17, 2020).

Iskandar, M. Pemerintah Indonesia Dorong Pengembangan eSports Nasional (Indonesian Government Encourages the Development of National eSports), available https://wartakota.tribunnews.com/2020/07/01/pemerintah-indonesiadorong-pengembangan-esports-nasional (last visited July 17, 2020).

Isna, R. S. R. Sri Mulyani Beberkan Tantangan Dirjen Pajak di Era Digital (Sri Mulyani Outlines the Challenges of the Director General of Taxes in the Digital Era), available at https://www.inews.id/finance/makro/sri-mulyani-beberkan-tantanganditjen-pajak-di-era-digital (last visited August 5, 2020).

Julita S., Lidya. Saat Dirjen Kemenkeu Cerita Kenapa Susah Memajaki Google Cs (When Director General of Ministry of Finance Tells Why It's Difficult to Tax Google Cs), available at https://www.cnbcindonesia.com/tech/20190717154401-3785636/saat-dirjen-kemenkeu-cerita-kenapa-susah-memajaki-google-cs $\quad$ (last visited August 5, 2020).

Kusuma, A. 4 Nama Besar Platform Streaming Terkait Video Games Beserta Pros Dan Cons (4 Name of the Platform Related Streaming Video Games And Its Pros And Cons), available at https://gamebrott.com/4-nama-besar-platform-streaming-terkaitvideo-games-beserta-pros-dan-cons (last visited June 4, 2020).

Malena. Industri Gaming Tumbuh 20 Persen, Ini 3 Alasan eSports Kian Populer (Gaming Industry Grows 20 Percent, These are 3 Reason eSports is Gaining More Popular), 
available at http://www.kalderanews.com/2020/07/industri-gaming-tumbuh20-persen-ini-3-alasan-esports-kian-populer/ (last visited August 18, 2020)

Muhammad, F. Bagaimana Cara Agar Youtuber Indonesia Mau Bayar Pajak? (How do you get Indonesian YouTubers to Pay Taxes?), available at https://www.cnbcindonesia.com/news/20190113154724-4-50418/bagaimanacara-agar-youtuber-indonesia-mau-bayar-pajak (last visited August 5, 2020).

Nanang, Z. A. BEPS Dalam Kerangka Kerja Sama G20 dan Implementasinya Kepad Indonesia (BEPS In the Framework of G20 Cooperation and Its Implementation to Indonesia), available at

Newzoo, The Global Esports Audience Will Be just Shy of 500 Million This Year, available at https://newzoo.com/insights/articles/newzoo-esports-sponsorship-alonewill-generate-revenues-of-more-than-600-million-this-year/ (last visited February 4, 2020).

Nordmark, S \& Heath, J. The top 10 highest prize pools in eSports, available at https://dotesports.com/general/news/biggest-prize-pools-esports-14605 (last visited May 16, 2020).

Nurhayat, W. Ekonomi Digital Jadi Tantangan Terberat Dirjen Pajak (Digital Economy Becomes the Most Challenging Director General of Taxes), available at https://kumparan.com/kumparanbisnis/ekonomi-digital-jadi-tantanganterberat-ditjen-pajak-27431110790545513/full (last visited August 5, 2020).

Rifki, B. Kemenpora "Godok" Undang-Undang Esports, Manfaatnya apa? (The Minister of Youth and Sports "Push" the Esports Law, What are the benefits?), available at https://esports.id/other/news/2020/02/0de5d1a081a3095d62b416e44e055e7a /kemenpora-godok-undang-undang-esports-manfaatnya-apa (last visited August 20, 2020).

Rizkia, C. Bisakah Skema Pungut Pajak Netfilx Mencontek Singapura? (Can Indonesia Imitate Singapore on the Netflix Tax Collection Scheme?), available at https://technologue.id/bisakah-skema-pungut-pajak-netflix-menconteksingapura/amp/ (last visited August 25, 2020)

Rizkia, C. Tiga Cara Gamer Menghasilkan Uang Dari Faceboook Gaming (Three Ways Gamers Make Money from Facebook Gaming), available at https:/ technologue.id/tiga-cara-menghasilkan-uang-dari-facebookgaming/amp/ (last visited July 8, 2020).

Setyo Wardani, Agustin, S. W. Menakar Format Turnamen Esports di Masa Pandemi (Measuring the Format of Esports Tournaments during the Pandemic), available at https://www.liputan6.com/tekno/read/4311170/menakar-format-turnamenesports-di-masa-pandemi (last visited August 20, 2020).

Situmorang, A.P. Ini Alasan YouTuber dan Selebgram Mangkir Bayar Pajak (This is the Reason Why YouTuber and Celebirty are Absent from Paying Taxes), available at https://www.merdeka.com/uang/ini-alasan-youtuber-dan-selebgrammangkir-bayar-pajak.html (last visited August 5, 2020).

Social Blade. Jess No Limit's YouTube Stats Summary, available at https://socialblade.com/youtube/channel/UCvh1at6xpV1ytYOAzxmqUsA (last visited May 9, 2020). 
Triyadi, B. Kemenpora dan IESPL Gelar Piala Menpora Esports 2020 (Kemenpora and IESPL Hold Menpora Esports Cup 2020), available at https://www.liputan6.com/bola/read/4322609/kemenpora-dan-iespl-gelarpiala-menpora-esports-2020 (last visited August 20, 2020).

World Economic Forum, The explosive growth of eSports, available at https://www.weforum.org/agenda/2018/07/the-explosive-growth-ofesports/ (last visited February 6, 2020).

World Economic Forum, The explosive growth of eSports, available at https://www.weforum.org/agenda/2018/07/the-explosive-growth-ofesports/ (last visited February 6, 2020).

Yadika, B. Facebook, YouTube dan Twitter Diminta Tiru Google soal Bayar Pajak (Facebook, YouTube and Twitter asked to imitate Google about Paying Taxes), available at https://www.liputan6.com/bisnis/read/4052109/facebook-youtube-dantwitter-diminta-tiru-google-soal-bayar-pajak (last visited August 25, 2020). 